\title{
Smallholder Livelihood Diversification and Income Inequality in Rural Malawi
}

\author{
Tsutomu Takane \\ Department of International Agricultural Development \\ Tokyo University of Agriculture \\ Hiroko Gono \\ Department of International Agricultural Development \\ Tokyo University of Agriculture
}

\begin{abstract}
Prior literature on rural livelihood diversification in Africa has suggested it has tended to increase inequality. Drawing on household data collected in nine Malawian villages over a decade, this paper examines the interrelationship between livelihood diversification and income inequality. Analysis of income portfolio and Gini coefficients shows that the interrelationship is highly varied and, in many cases, livelihood diversification decreases inequality. The varied situations stem from different contexts, such as proximity to a major town, entry barriers to off-farm activities, and variability of own-farm income. The highly variable situations found in rural Malawi call for a more context-specific policy intervention, rather than a nationwide single prescription.
\end{abstract}

Keywords: income; livelihood; inequality; diversification; Malawi; Africa

\section{INTRODUCTION}

Rural livelihood diversification among smallholder farmers in developing countries has attracted much attention from policy makers and academics in the past decades. This is because livelihood diversification can potentially reduce the vulnerability of smallholder farmers by providing opportunities for additional income, income smoothening, risk reduction, and coping with shocks. Supporting livelihood diversification has also been seen by scholars and policymakers as an important means to offer escape from poverty for smallholder farmers (Ellis, 2000; Matsumoto et al., 2006; World Bank, 2007).

Whether the widely observed livelihood diversification increases or decreases income inequality among smallholder farmers has been subject to empirical investigation. Literature across different regions in developing countries has observed no consistent patterns of interrelationship between nonfarm earning and income distribution (Reardon et al., 2000; Lanjouw and Lanjouw, 2001; Haggblade et al., 2010). In the case of rural Africa, however, many studies have indicated that nonfarm employment has tended to increase income inequality. For example, Loison (2015) maintained it was the better-off smallholders with sufficient assets who achieved successful livelihood diversification, while the large majority of smallholders did not benefit from incomes and wealth based on livelihood diversification. Similarly, Reardon et al. (2000) and Barrett et al. (2001) argued that many poor smallholders were unable to overcome entry barriers to highly remunerative nonfarm activities, leaving them with fewer remunerative activities. When livelihood diversification occurred among the poor, it was through increased unskilled labour that did not increase household income or reduce risk exposure. Lay et al. (2008) also found that, in western Kenya, high-return non-agricultural 
activities enabled richer households to increase agricultural productivity, while engagement in low-return activities among poor households did not affect agricultural productivity. The inequality-enhancing effects of nonfarm activities were also reported by other empirical studies (Canagarajah et al., 2001; Ellis et al., 2004; Lay et al., 2008).

Conversely, some empirical studies have reported an inequality-decreasing effect of the nonfarm sector (Adams, 2002; van den Berg et al., 2006; Kamanga et al., 2009). For example, in their study in Oromia, Ethiopia, van den Berg et al. (2006) found that entry barriers to nonfarm activities were low, the poor earned more income from nonfarm activities, and, thus, nonfarm income decreased total inequality. This finding contradicts much of the evidence from other African countries and from other studies specifically investigating Ethiopia (Block et al., 2001; Bezu et al., 2012). On the other hand, Reardon and Taylor (1996) in their study on Burkina Faso reported the different effects of off-farm income on income inequality across agroclimatic zones and between normal and drought years. These varied results in the literature provide a warning against overgeneralization, and there is a need for more context-specific studies on this issue.

This paper contributes to the existing literature on livelihood diversification and income inequality in rural Africa by offering a micro-level analysis of nine villages across locations, years, and socioeconomic backgrounds in Malawi. The aim is to provide evidence of highly varied patterns of rural diversification and income inequality within the country. Based on the study results, the paper argues for multi-faceted policy interventions that consider diverse local contexts and strategies adopted by smallholder households, rather than a nationwide single policy prescription.

The paper is organized as follows. In section two, we summarize the patterns of interrelationship between livelihood diversification and income inequality. Section three explains the contexts of rural livelihood in Malawi and the study methods. Section four examines income portfolio, share of off-farm income by income strata, and the effects of offfarm income on inequality in study villages. Section five provides conclusions and policy implications.

\section{PATTERNS OF LIVELIHOOD DIVERSIFICATION AND INCOME INEQUALITY IN RURAL AFRICA}

Two major patterns of rural livelihood diversification are identified in the literature (Ellis, 2000; Barrett et al., 2001; Haggblade et al., 2010; Loison, 2015). One is survival-led diversification (also referred to as distress-led diversification), in which individuals and households diversify their economic activities by necessity of survival. Survival-led diversification is typically found in situations of low-productivity and high-risk agriculture, seasonality of economic activities, and prevalence of poverty. Where agriculture faces high risk, smallholder households diversify their economic activities into non-agricultural sectors, either as an ex-ante risk management strategy or an ex-post coping strategy, though these strategies may be insufficient to stabilise income (Dearcon, 2002; Kijima et al., 2006). The same diversification strategy could also spread the timing of income throughout a year, contributing to income and consumption smoothening. The negative factors that force smallholder households to seek multiple income sources to survive are often called 'push' factors in the literature.

Another pattern is opportunity-led diversification, which is mainly driven by 'pull' factors, such as availability of remunerative income opportunities, increasing demand for locally produced goods, and accumulation objectives and income-maximizing motives of individuals and 
households. Opportunity-led diversification occurs where a dynamic economic environment incentivises smallholder households to engage in high-return economic activities. Such activities may require a certain level of asset endowment (cash, land, social networks, education, and skills) of each individual or household. If the required assets are owned mainly by rich households, the poor households face entry barriers to engage in more remunerative off-farm income.

Survival-led and opportunity-led diversification may not be mutually exclusive. For example, poor smallholder households could diversify their portfolio of activities with the aim of spreading risk over multiple activities, smoothening income, and maximizing income through allocation of available household labour over different times and on multiple activities. Livelihood diversification, therefore, potentially provides the rural poor with, simultaneously, both a means of survival and an opportunity for upward mobility, though this pattern is not always automatic (Lay et al., 2008; Kamanga et al., 2009).

In addition, linkages exist between own-farm income and off-farm income that are complementary to and reinforce each other (Reardon et al., 2000; Ellis et al., 2004; Lay et al., 2008). For example, cash income from off-farm activities can be used to buy recurrent farm inputs, such as fertilizer and modern varieties of seed that will increase agricultural productivity and farm income, or to buy farm equipment and livestock that will increase their asset base (Lay et al., 2008; Kamanga et al., 2009; Kamlongera 2011). Similarly, income from sales of farm surpluses can be invested in high-return, off-farm economic activities. This complementary and reinforcing relationship through investment is found mostly among better-off households, because very poor households tend to use their income for immediate consumption needs rather than for investments in productivity-enhancing inputs and assets.

The pattern of the relationship between share of off-farm income and household wealth status can be positive, negative, U-shaped, inverted U-shaped, or non-existent (Lay et al., 2008; Reardon et al., 2000; Loison 2015). In the positive pattern, the share of off-farm income in total household income increases as the latter increases. Richer households show a diversified portfolio of activities, while poorer households tend to earn most of their income from farming. When opportunity-led diversification occurs only among richer households and poorer households face entry barriers to engage in highly remunerative off-farm activities, it increases the inequality among the rural households.

In the negative relationship pattern, the share of off-farm income in total household income is larger among the poor than among the rich. This pattern can be found in the situation where survival-led or opportunity-led diversification is widespread among the poor, while ownfarming is the major income source among wealthier households. If the absolute level of offfarm income earned by poorer households is higher than that earned by wealthier households, the effect of this pattern could be inequality-decreasing.

In the U-shaped pattern, the share of off-farm income in the total household income is high for the poorest households, decreases in the middle-income households, and then increases for the wealthiest households. Although both the poorest and richest households diversify, the types of off-farm activities in which the two groups engage may be different. Typically, the poor households diversify into low-return and low-entry-barrier activities, while the rich households engage in high-return activities posing high entry barriers in terms of required financial and human capital. As the absolute level of off-farm income is usually higher among the rich households, the pattern often indicates an inequality-increasing effect. 
In the inverted U-shaped pattern, only the middle-income households exhibit a high share of off-farm income, while the poorest and richest households have a low share thereof. The low level of diversification among the poorest households may signify that the poor, despite their insufficient income from own-farming due to small landholdings, cannot diversify into off-farm activities to earn additional income due to some forms of entry barriers. Conversely, the high share of farm income among the richest households implies that they specialize in farm production and earn high farm income, which is made possible by a large landholding, adoption of improved production technology, production of high-value crops, or a combination of these.

Analysis of livelihood diversification and income inequality requires examination of these patterns, which are often conditioned by specific local and wider contexts. The important local contexts include access to markets, proximity to urban areas, conditions of infrastructure, availability of land, and formal and informal institutions that govern access to and control over resources. Wider contexts that affect rural livelihood are, among others, national policies, technological change, price changes, and the natural environment, such as weather and soil conditions (Carney, 1998; Scoones, 1998). As livelihood analysis is inherently context-specific, the analysis that follows focuses particularly on the different contexts in which livelihood diversification occurs.

\section{Context of rural livelihood in Malawi}

\section{THE MALAWI CONTEXT AND STUDY METHODS}

Poverty and food insecurity are widespread among Malawi's rural population. According to the World Development Indicators of the World Bank, about half of its population lived below the national poverty line in 2010. The country's gross national income per capita (US\$350 in 2015) was ranked at 215 th of the 217 countries on which statistics were available. The national production level of maize, the staple food, fluctuates widely depending on each year's weather conditions. Due to increasing population pressure on the land, rural households operate very small farm sizes, averaging 0.88 hectares in 2013 (Government of Malawi, 2014). The high prices of productivity-enhancing inputs, such as chemical fertilizer and improved varieties of seeds, prevented many smallholders from adopting them. Consequently, about 60 percent of smallholder households were not self-sufficient but net buyers of maize (Dorward et al., 2007). Due to the high risk and low productivity of agricultural production, many smallholder households diversified their economic activities into non-crop sectors (Ellis et al., 2003; Takane, 2008b).

Against this background, the main focus of Malawi's government's policies in the past two decades has been to increase the maize production of smallholder households. In 1998, the government launched the Starter Pack Program and distributed free input packages containing sufficient hybrid maize seeds and fertilizer to cultivate 0.1 hectares. That program was replaced in 2005 by the Agricultural Input Subsidy Programme, in which eligible farmers received coupons that could be redeemed for fertilizer and seeds at heavily subsidized prices (Chirwa and Dorward, 2013). In 2006, the government also launched the Social Cash Transfer Program that provided ultra-poor and labour-constrained households with monthly cash payments (Handa et al., 2012). While these policies were implemented, Malawi occasionally experienced acute food shortages caused by bad weather.

\section{Study Villages and Methods}

Fieldwork for this study was conducted in nine villages in different parts of Malawi and household income data was collected for the years 2004 to 2015 (Figure 1). The study villages were selected purposefully based on two criteria. The first was to represent several 
socioeconomic characteristics, such as location, predominant ethnic group, degree of population pressure on land, variations in access to off-farm activities, and proximity to or remoteness from trading centres. The second criterion was to select villages representing the maize-centred agriculture that dominates in Malawi's smallholder sector. The aim of this selection procedure was to include various socioeconomic situations in which typical smallholder production was active, and this study's results should not be taken as representing national patterns in a statistical sense.

Simple random sampling was used to select households in each study village for detailed interviews, but, in some villages, stratified random sampling based on growers and nongrowers of tobacco (a major cash crop in Malawi) was used to ensure the inclusion of two groups. The income data of sample households (271 in total) was collected, and, in three villages, panel data was obtained for different years. A structured questionnaire was used to collect income data during the interviews, and free discussion was encouraged to elaborate important issues related to livelihood strategies adopted by household members. In addition, the farms operated by sample households were measured using global positioning systems to obtain accurate data on the size of the plots (Holden and Fisher, 2013). Key respondent interviews were also conducted to obtain such information as village history and land tenure systems. Interviews with farmers were conducted by the research assistants, who were fluent in the local languages; the authors attended, recorded, and reviewed all the interviews. The major characteristics of the study villages are summarized in Table 1.

The criteria for classifying income sources are important in the analysis of livelihood diversification. Following Loison (2015), the components of rural livelihood diversification can be classified in three ways: by sector (agricultural or non-agricultural), by function (wage employment or self-employment), and by location (on own farm or off own farm). For the purpose of this paper, we adopted the classification of household income by location for two reasons. First, as the low level of agricultural productivity among smallholder farmers continues to be a major challenge in Malawi, income from own-farm production needs to be examined separately from income from other economic activities. Second, location-based income classification enables us to analyse casual wage labour (called ganyu in Malawi) as a separate category of income source. Ganyu in agricultural and non-agricultural sectors constitutes an important livelihood means in the context of rural Malawi (Bryceson, 2006; Whiteside 2000).

Own-farm income constitutes income from crop and livestock production (including the imputed value of home-consumed crops and livestock). Off-farm income includes income from ganyu casual labour, salaried employment, nonfarm self-employment, and other sources such as remittance from relatives living outside the study villages. We did not include government transfers (such as cash income through the Cash Transfer Programme) in the off-farm income, because the values of government transfers were substantial and their inclusion would distort the wealth status and income portfolio of many households, especially the poor. In addition, we did not include the imputed value of land rent and of family labour involved in crop and livestock production because of the difficulty of estimation.

\section{Income portfolio}

\section{RESULTS AND DISCUSSION}

Analysis of income portfolios in the study villages (Table 2) showed considerable variations in the relative importance of economic activities, and several features can be highlighted. First, high shares of own farm income were mostly observed in remote villages. The two villages 
with the highest share of own-farm income (Kachamba and Mulawa) were both located in remote areas, and their remoteness was reflected in the limited economic opportunities outside agriculture in those villages. The shares of own-farm income in the other two remote villages (Belo and Epiphi) were much lower than those of Kachamba and Mulawa, but still higher than those of the villages with better access to a major town.

In contrast, high shares of off-farm income are observed in the villages with good access to a major town, namely Bongololo, Mbila, Chalya, and Yamba. This proximity to a major town enabled some villagers to engage in low-entry-barrier nonfarm self-employment, such as brewing local beer and collecting stones for construction for which there was demand in town. Other villagers found salaried jobs, such as watchman and low-ranked workers in local government offices. Within off-farm income, income from nonfarm self-employment and salaried jobs appeared to be high, though the relative importance of these two income sources varied across study villages.

Third, the income from ganyu casual labour as a share of total income was low in all the villages. However, this does not mean that few villagers engaged in ganyu, as 51 percent of the sampled households contained at least one member who did so; rather, the low share of total income derived from the low wages and ad hoc nature of ganyu casual labour. Although ganyu provided a low-entry-barrier income opportunity for many, especially poor, households, the contribution of ganyu to increasing total household income was evidently limited.

Fourth, in the three villages where the panel data were collected twice, with a five-year interval, the income portfolios showed fairly constant patterns between the years. Own-farm income constituted a major source of income in Kachamba, while incomes from salaried job and nonfarm self-employment showed high percentage shares in Chalya and Yamba in both the survey years. This implies that the livelihood portfolio of smallholder households did not change considerably over a short period.

Fifth, very low shares of own-farm income were observed in Holo and Mbila, where drought caused the harvest to be very small in 2005. Consequently, the total household incomes in these two villages were among the lowest among all the study villages. As most households experienced very low own-farm income, the level of off-farm income virtually determined the household income status. This signifies the importance of off-farm income in the highly uncertain situation of agricultural production in Malawi.

\section{Share of off-farm income and household wealth status}

Examination of share of off-farm income by income strata also revealed varied relationship patterns (Table 3). Positive patterns were observed in Chalya in 2009 and Yamba in 2014. As these villages are located within walking distance of major towns, many households in all the income strata engaged in off-farm activities. The types of off-farm activities differed between the poor households on the one hand and the middle-income and rich households on the other. The poor households engaged mostly in ganyu casual labour on an ad hoc basis, while betteroff households engaged in regular salaried jobs or nonfarm self-employment, such as brewing local beer and selling cooked food. The proximity to major towns created a year-round demand for local beer and other goods, making nonfarm self-employment a semi-regular income earning source.

Contrary to most of the existing literature, these opportunity-led diversification strategies in the villages near major towns did not pose high entry barriers. For example, brewing local beer and selling cooked food were relatively profitable activities but did not require much initial 
capital to start, and were, thus, widely practiced by many households. The salaried jobs in which villagers engaged were night watchman and manual labourer, which did not require high education levels. Access to these jobs originated mainly from better access to a major town, rather than households' financial or human capital endowment. The low entry barrier to engagement in off-farm activities probably reflected the limited development of the nonfarm sector in general in Malawi.

The remote village of Belo also showed a positive relationship pattern, as a representative case of entry barriers to highly remunerative off-farm jobs. Due to its remoteness, opportunities for low-entry-barrier off-farm activities were limited in Belo. The village's only off-farm employment with high remuneration was the role of primary school teacher. Three of the sample households contained teachers, all of whom were positioned in the highest income strata. The entry barrier of the required education level was relatively high for this job, as the average education years of teachers (12.0 years) was much higher than that of other household heads (2.7 years). Thus, the case of Belo accords with the tendency noted in the literature that only those with a capital endowment (in this case, human capital) can engage in highly remunerated off-farm employment (Neudert at al., 2015).

Among those engaged in highly remunerated off-farm activities, some cases of complementary linkages between own-farm and off-farm activities were observed. Many households used offfarm income to purchase chemical fertilizer and to employ casual labourers to increase farm productivity. However, there were two obstacles that prevented some households benefiting from the linkages. One was inflexibility of time allocation between own-farm and off-farm activities. Those who engaged in regular salaried jobs had little time to work on their own farm and often experienced low own-farm income due to low productivity caused by insufficient farm care. The second was limited access to land among female-headed households. In many societies in northern Malawi, patrilineal inheritance systems restrict women's land rights, and female-headed households have few opportunities to invest their off-farm income in ownfarming (Takane 2008a).

In contrast to the villages that showed positive relationship patterns between total household income and the share of off-farm income, Kachamba represented a clear negative pattern. The share of off-farm income among the rich households in Kachamba was the lowest of all the strata of the study villages, meaning that the rich households in the village achieved high income by concentrating on own-farm production. The high own-farm income was made possible by their large farm sizes and high land productivity. In addition, the rich households reinvested their income into own farming by employing farm labourers, renting additional land for farming, and purchasing fertilizers and livestock. As the village is located far away from major town, highly remunerative off-farm employment was not available. Consequently, the incentive of opportunity-led diversification was weak, and the richer households chose not to reinvest own-farm income in off-farm activities but rather to reinvest in agriculture by expanding and intensifying their own farming to achieve high levels of production. Conversely, poorer households opted for survival-led diversification strategies of supplementing low ownfarm income with low off-farm income, such as from ganyu. The remoteness and unavailability of remunerative off-farm activities led to weak linkages between own-farm and off-farm income. Reinvestment occurred within own-farm production and only among rich households. U-shaped patterns are found in Horo and Epiphi. Prior literature has suggested that, in the Ushaped pattern, the different types of off-farm activities between the poor and rich households determine the level of off-farm income, as rich households engage in capital intensive highreturn activities while the poor engage in low-return and low-entry-barrier activities. This was 
somewhat true in Horo and Epiphi, as poor households mostly engaged in poorly-paid ganyu casual labour on an ad hoc basis. In Epiphi, while 95\% of poor households engaged in ganyu, only $5 \%$ of them engaged in off-farm activities other than ganyu. In contrast, richer households obtained higher income from off-farm activities, such as small-scale trading, for which one needs initial start-up capital. Some rich households in Epiphi obtained high income from handicraft-making that also required skills (human capital). These cases showed that the types of off-farm activities and their entry barriers were different between poor and rich households. However, the asset endowments required for off-farm activities among the rich households are only 'high' in relative terms: these entry barriers may only be high in the context of rural Malawi and would be regarded as very low in some other developing countries.

In Mulawa, we found an inverted-U shaped pattern that originated from the difference in farm size across income strata. Both poor and rich households operated larger farms (on average 1.35 ha and 1.48 ha respectively) than middle-income households ( 0.69 ha). This U-shaped pattern of farm sizes contributed to the inverted-U shaped relationship pattern between the share of off-farm income and wealth status. It also signified that a large farm size would not guarantee a high total income, given the high variability of farm productivity between households. These findings differ from the tendency observed in the literature that the size of landholdings explains the different income levels between poor and rich households. Conversely, the types of off-farm activities in which both poor and rich households engaged were similar and did not require capital. This means there was no difference in the entry barriers to off-farm activities in which households with different wealth status engaged. This finding, again, does not accord with the tendency noted in the literature that poor households face entry barriers to off-farm activities while rich households engage in off-farm activities that require capital.

Chalya and Yamba, in which panel data were obtained in 2009 and 2014, showed different relationship patterns in each year studied. In Chalya, the pattern was positive in 2009 but Ushaped in 2014. This difference stemmed from the low levels of own-farm income in 2014 among the poor households, due to the high input costs of fertilizer and seed. Because of the low own-farm income, off-farm income as a share of total income among the poor households in 2014 became high, even though the absolute level of off-farm income in 2014 was lower than that of 2009. In the case of Yamba, low own-farm income caused by high input costs was experienced among the rich households. In fact, the high input costs in 2014 made the average own-farm income of rich households much lower than that of poor households, resulting in a high share of off-farm income among the rich households. These cases indicate that, under the condition of high yearly variability of own-farm income, the relationship pattern between share of off-farm income and household wealth status change considerably over time, and a judgement based on data in a particular year might, therefore, be misleading.

\section{Gini coefficients with and without off-farm income}

To examine whether off-farm income increased or decreased income inequalities among households, Gini coefficients of household income per adult equivalent unit (AEU) with and without off-farm income were calculated (Table 4). A positive change of Gini coefficient for without off-farm income indicates that off-farm income has an inequality-decreasing effect, while a negative change indicates an inequality-increasing effect (Kamanga et al., 2009).

In the study villages, off-farm income reduced income inequality in most cases. In particular, ganyu casual labour appeared to have reduced income inequality in all villages. This indicates that many poor and middle-income households supplemented low own-farm income with 
income from ganyu in all contexts. However, as the level of income from ganyu was low, the magnitude of its inequality-decreasing effect was limited in most cases.

Examining the effect of all off-farm income, the inequality-increasing effects were found in three cases, namely Epiphi, Chalya in 2009, and Yamba in 2014. A common feature of the three cases is that the Gini coefficients of per AEU own-farm income are small, signifying the relatively equal distribution of own-farm income among households. The relatively equal distribution was changed by the different levels of off-farm income earned by households; thus, the off-farm income had inequality-increasing effects. The magnitude of inequality-increasing effects was larger in villages with good access to major town (Chalya and Yamba) than in a remote village (Epiphi) because of the better availability of off-farm income opportunities in the former.

The smaller Gini coefficients of per AEU own-farm income appeared to be associated with relatively equal distribution of farm sizes, as the three villages (Epiphi, Chalya, and Yamba) also showed relatively small Gini coefficients of per AEU farm size. However, this association was not automatic, because the panel data of Chalya and Yamba indicated large differences in Gini coefficients of per AEU own-farm income between 2009 and 2014. In Chalya, for example, Gini coefficients of both per AEU farm size and per AEU own-farm income in 2009 were small ( 0.33 and 0.35 respectively), while, in 2014, the Gini coefficient of per AEU own-farm income increased by 0.27 . This increase was due to the low own-farm income (caused by the high input costs in 2014) experienced by the poorer households. In Yamba, the same high input costs adversely affected richer households, resulting in a decrease in the Gini coefficient of per AEU own-farm income by 0.15 from 2009 to 2014. Different farm sizes among households contribute to increasing inequality in a year with low input costs and a good harvest. However, in a year with adverse conditions, they would result in decreasing inequality, because households with a large farm size would suffer more than those with a small farm size. Highly uncertain natural and socioeconomic environments surrounding farm production, and the resultant variability of own-farm income among households and between years, caused unpredictable relationship patterns between the share of off-farm income and inequality.

\section{CONCLUSION AND POLICY RECOMMENDATIONS}

This study has shown that the interrelationship between the share of off-farm income and inequality in Malawi is highly varied and context-dependent. Factors that affected the interrelationship include access to a major town, varied entry barriers to off-farm activities, and high variability of own-farm income among households and between years. Household investment strategies also varied, as some reinvested income across off-farm and own farm activities, while others faced obstacles to reinvesting due to lack of access to land or opportunities, and still others reinvested within farm production. Overall, the underdevelopment of non-farm sectors in rural Malawi created few opportunities for highly remunerated off-farm activities that would increase income inequalities. Under such conditions, poor households supplemented low own-farm income with low off-farm income by engaging in low-entry-barrier activities, while rich households adopted varied strategies that placed different emphasis on own-farm and off-farm activities under different conditions. The important features found in the study villages were uncertainty and unpredictability. An observed pattern of farm and off-farm income shares on the one hand, and the interrelationship between that pattern and inequality on the other, may considerably change in different locations and in different years. 
The highly variable situations found in rural Malawi call for a more context-specific policy intervention than a nationwide single prescription. For example, in remote rural areas where off-farm opportunities are limited and households derive their income mostly from agriculture, reducing the risks and uncertainty in farm production (such as through small-scale irrigation) or easing access to markets for farm produce (such as through better feeder roads) may be present feasible options, as these will increase the income of both poor and rich households. In the areas where female access to land is restricted, interventions that focus on increasing offfarm income opportunities by enhancing human capital endowment among women (such as through skills training in handicraft or food processing) and increasing material asset bases (for example, by providing tools and machines necessary for off-farm activities) would be effective in increasing the income of female-headed households. Support that focuses exclusively on farm production would not benefit landless female-headed households and poor households with very small farm sizes or with little family labour. Policy makers need to adopt a multi-faceted approach that reflects the high variability of livelihood situations across locations and years.

The principal limitation of this study is that its analysis is based mainly on data obtained from villages representing maize-centred agriculture. Although this form of agriculture dominates in Malawi's smallholder sector, other types of agriculture (such as tobacco-centred) also exist in the country. Further research is needed to investigate the interrelationship between livelihood diversification and income inequality in areas where different crops dominate smallholder agriculture.

\section{ACKNOWLEDGEMENTS}

This study was supported by JSPS KAKENHI Grant Number $15 \mathrm{~K} 07635$ and the Institute of Developing Economies (IDE-JETRO).

\section{References}

Adams, RH, 2002. Nonfarm income, inequality, and land in rural Egypt. Economic Development and Cultural Change 50(2), 339-363.

Barrett, CB, Reardon, T \& Webb, P, 2001. Nonfarm income diversification and household livelihood strategies in rural Africa: concepts, dynamics, and policy implications. Food Policy 26, 315-331.

Bezu, S, Barrett, CB, \& Holden, ST, 2012. Does the nonfarm economy offer pathways for upward mobility? Evidence from a panel data study in Ethiopia. World Development 40(8), 1634-1646.

Block, S \& Webb, P, 2001. The dynamics of livelihood diversification in post-famine Ethiopia. Food Policy 26, 333350 .

Bryceson, DF, 2006. Ganyu casual labour, famine and HIV/AIDS in rural Malawi: causality and casualty. Journal of Modern African Studies 44(2), 173-202.

Canagarajah, S, Newman C, \& Bhattamishra, R, 2001. Non-farm income, gender, and inequality: Evidence from rural Ghana and Uganda. Food Policy 26, 405-420.

Carney, D, 1998. Implementing the sustainable rural livelihoods approach. In Carney, D (Ed.), Sustainable rural livelihoods: What contribution can we make? Department for International Development, London.

Chirwa, E \& Dorward, A, 2013. Agricultural input subsidies: the recent Malawi experience. Oxford University Press, Oxford.

Dearcon, S, 2002. Income risk, coping strategies, and safety nets. The World Bank Research Observer 17(2), 141166.

Dorward, A, Chirwa, E, Kelly, V, Jayne, T, Slater, R \& Boughton, D, 2007. Evaluation of the 2006/07 agricultural input subsidy programme, Malawi. Report to the Ministry of Agriculture and Food Security.

Ellis, F, 2000. The determinants of rural livelihood diversification in developing countries. Journal of Agricultural Economics 51(2), 289-302. 
Ellis, F, Kutengule, M \& Nyasulu, A, 2003. Livelihoods and rural poverty reduction in Malawi. World Development 31(9), 1495-1510.

Ellis, F \& Freeman, HA, 2004. Rural livelihoods and poverty reduction strategies in four African countries. Journal of Development Studies 40(4), 1-30.

Government of Malawi, 2014. Integrated household panel survey 2010-2013: Household socio-economic characteristics report. National Statistical Office, Zomba.

Haggblade, S, Hazell, P \& Reardon, T, 2010. The rural non-farm economy: prospects for growth and poverty reduction. World Development 38(10), 1429-1441.

Handa, S, Huang, C, Hypher, N, Texeira, C, Veras, F \& Davis, B, 2012. Targeting effectiveness of social cash transfer programs in three Africa countries. Journal of Development Effectiveness 14(1), 78-108.

Holden, ST \& Fisher, M, 2013. Can area measurement error explain the inverse farm size productivity relationship? Centre for Land Tenure Studies Working Paper 12/13, Norwegian University of Life Sciences.

Kamanga, P, Vedeld, P \& Sjaastad, E, 2009. Forest incomes and rural livelihoods in Chiradzulu District, Malawi. Ecological Economics 68, 613-624.

Kamlongera, PJ, 2011. Making the poor 'poorer' or alleviating poverty? Artisanal mining livelihoods in rural Malawi. Journal of International Development 23, 1128-1139.

Kijima, Y, Matsumoto, T \& Yamano, T, 2006. Nonfarm employment, agricultural shocks, and poverty dynamics: Evidence from rural Uganda. Agricultural Economics 35(supplement), 459-467.

Lanjouw, JO \& Lanjouw, P, 2001. The rural non-farm sector: Issues and evidence from developing countries. Agricultural Economics 26, 1-23.

Loison, SA, 2015. Rural livelihood diversification in sub-Saharan Africa: A literature review. Journal of Development Studies 51(9), 1125-1138.

Lay, J, Mahmoud, TO, \& M'Mukaria, GM, 2008. Few opportunities, much desperation: The dichotomy of nonagricultural activities and inequality in western Kenya. World Development 36(12), 2713-2732.

Matsumoto, T, Kijima, Y \& Yamano, T, 2006. The role of local nonfarm activities and migration in reducing poverty: Evidence from Ethiopia, Kenya, and Uganda. Agricultural Economics 35(supplement), 449-158.

Neudert, R, Goetter, JF, Andriamparany, N. \& Rakotoarisoa, M, 2015. Income diversification, wealth, education and well-being in rural south-western Madagascar: Results from the Mahafaly region. Development Southern Africa 32(6), 758-784.

Reardon, T \& Taylor, JE, 1996. Agroclimatic shock, income inequality, and poverty: Evidence from Burkina Faso. World Development 24(5), 901-914.

Reardon, T, Taylor, JE, Stamoulis, K, Lanjouw, P \& Balisacan, A, 2000. Effects of non-farm employment on rural income inequality in developing countries: An investment perspective. Journal of Agricultural Economics 51(2), 266-288.

Scoones, I, 1998. Sustainable rural livelihoods: A framework for analysis. IDS Working Paper No.72, Institute of Development Studies, Brighton.

Takane, T, 2008a. Customary land tenure, inheritance rules, and smallholder farmers in Malawi. Journal of Southern African Studies 34(2), pp.269-291.

Takane, T, 2008b, African rural livelihoods under stress: economic liberalization and smallholder farmers in Malawi. Institute of Developing Economies (Occasional Papers Series No.42), Chiba.

Van Den Berg, M \& Kumbi, GE, 2006. Poverty and the rural nonfarm economy in Oromia, Ethiopia. Agricultural Economics 35, 469-475.

Whiteside, M, 2000. Ganyu labour in Malawi and its implications for livelihood security interventions: An analysis of recent literature and implications for poverty alleviation. Agricultural Research and Extension Network Paper No.99, Overseas Development Institute.

World Bank, 2007. World development deport 2008: agriculture for development. The World Bank, Washington, DC. 
Figure 1: Study Locations

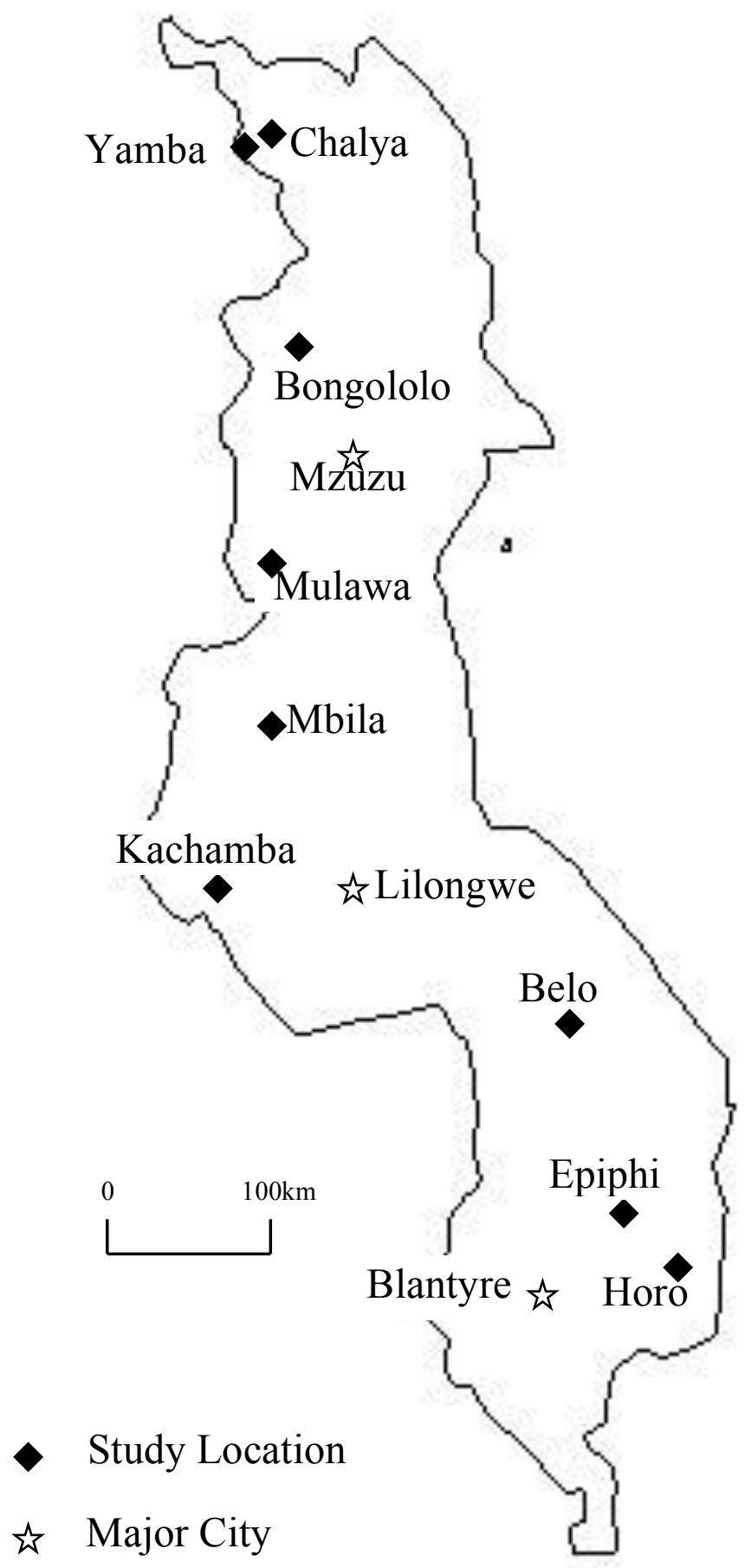


Takane, T., \& Gono, H. (2017). Smallholder Livelihood Diversification and Income Inequality in Rural Malawi. Advances in Social Sciences Research Journal, 4(13) 40-53.

\begin{tabular}{|c|c|c|c|c|c|}
\hline \multicolumn{6}{|c|}{ Table 1: Study villages } \\
\hline $\begin{array}{l}\text { Access to } \\
\text { major } \\
\text { tow } n\end{array}$ & V illage nam e & Year of study & $\begin{array}{l}\text { Num ber } \\
\text { of } \\
\text { sam ples }\end{array}$ & $\begin{array}{l}\text { Average fam } \\
\text { size per } \\
\text { household } \\
\text { (ha) }\end{array}$ & $\mathrm{D}$ istance to $\mathrm{m}$ ajor tow $\mathrm{n}$ and other rem arks \\
\hline \multirow{4}{*}{$\mathrm{B}$ ad } & Kacham ba & 2004,2009 & 23 & $\begin{array}{ll}1.1 & (2004) \\
1.0 & (2009)\end{array}$ & $38 \mathrm{~km}$ w ith no regular transport \\
\hline & Beb & 2004 & 30 & 1.8 & $42 \mathrm{~km}$ w th no regu lar transport \\
\hline & Mu law a & 2005 & 28 & 1.2 & $20 \mathrm{~km}$ w th no regular transport \\
\hline & Epphi & 2015 & 57 & 0.5 & $39 \mathrm{~km}$ w ith no regular transport. \\
\hline Moderate & Horo & 2005 & 33 & 0.6 & $15 \mathrm{~km}$ w ith occas ional transport Experienced drought \\
\hline \multirow{4}{*}{ Good } & Bongo $\mathrm{b} \mathrm{b}$ & 2005 & 33 & 0.8 & $2 \mathrm{~km}$ to adjacent town. \\
\hline & M bila & 2005 & 32 & 0.9 & $5 \mathrm{~km}$ to district capital Experienced drought \\
\hline & Chalya & 2009,2014 & 18 & $\begin{array}{ll}0.7 & (2009) \\
0.6 & (2014)\end{array}$ & $2 \mathrm{~km}$ to district capital \\
\hline & Yam ba & 2009,2014 & 17 & $\begin{array}{ll}1.4 & (2009) \\
1.1 & (2014) \\
\end{array}$ & $3 \mathrm{~km}$ to district capital \\
\hline
\end{tabular}

Table 2: Sources of ncome in study villages on the basis of total household incom e per AEU (adult equ inalent un it)

\begin{tabular}{|c|c|c|c|c|c|c|c|c|}
\hline \multirow[b]{3}{*}{$\begin{array}{l}\text { Access to } \\
\text { major } \\
\text { town }\end{array}$} & \multirow[b]{3}{*}{ Study village (year) } & \multirow[b]{3}{*}{$\begin{array}{l}\text { Num ber } \\
\text { of } \\
\text { samples }\end{array}$} & \multirow{3}{*}{$\begin{array}{c}\text { Average } \\
\text { total } \\
\text { ncom e } \\
\text { per AEU } \\
\text { (MK) }\end{array}$} & \multicolumn{5}{|c|}{ Percent of total incom e per AEU from } \\
\hline & & & & \multirow[b]{2}{*}{$\begin{array}{l}0 \text { w n-farm } \\
\text { ncom e } \\
\text { (crop and } \\
\text { linestock) }\end{array}$} & \multicolumn{4}{|c|}{$0 \mathrm{ff}-$ farm incom e } \\
\hline & & & & & $\begin{array}{l}\text { Casual } \\
\text { labor } \\
\text { (ganyu) }\end{array}$ & $\begin{array}{c}\text { Nonfarm } \\
\text { se lf- } \\
\text { em pbym e } \\
\text { nt }\end{array}$ & $\begin{array}{l}\text { Salaried } \\
\text { jb }\end{array}$ & 0 thers \\
\hline \multirow{5}{*}{ B ad } & Kacham ba (2004) & 23 & 7,177 & $75.6 \%$ & $1.7 \%$ & $14.1 \%$ & $8.3 \%$ & $0.3 \%$ \\
\hline & Kacham ba (2009) & 23 & 14,984 & $88.3 \%$ & $2.8 \%$ & $4.5 \%$ & $4.0 \%$ & $0.4 \%$ \\
\hline & Beb (2004) & 30 & 9,386 & $45.3 \%$ & $1.9 \%$ & $21.8 \%$ & $27.3 \%$ & $3.6 \%$ \\
\hline & M u law a (2005) & 28 & 7,010 & $86.3 \%$ & $1.7 \%$ & $8.6 \%$ & $0.0 \%$ & $3.4 \%$ \\
\hline & Epph i (2015) & 57 & 4,895 & $42.4 \%$ & $16.6 \%$ & $24.0 \%$ & $11.4 \%$ & $5.6 \%$ \\
\hline Moderate & Horo (2005) & 33 & 2,428 & $-46.3 \%$ & $10.9 \%$ & $93.4 \%$ & $0.0 \%$ & $42.1 \%$ \\
\hline \multirow{7}{*}{ Good } & B ongo b b (2005) & 33 & 11,767 & $28.4 \%$ & $2.0 \%$ & $58.3 \%$ & $10.2 \%$ & $1.0 \%$ \\
\hline & M bila (2005) & 32 & 4,984 & $5.7 \%$ & $9.9 \%$ & $25.9 \%$ & $31.4 \%$ & $27.2 \%$ \\
\hline & Chalya (2009) & 18 & 11,517 & $25.1 \%$ & $3.5 \%$ & $7.4 \%$ & $52.6 \%$ & $11.3 \%$ \\
\hline & Chalya (2014) & 18 & 12,217 & $12.5 \%$ & $7.0 \%$ & $20.6 \%$ & $55.1 \%$ & $4.9 \%$ \\
\hline & Yam ba (2009) & 17 & 15,524 & $30.6 \%$ & $3.0 \%$ & $42.8 \%$ & $11.7 \%$ & $11.8 \%$ \\
\hline & Yam ba (2014) & 17 & 12,234 & $14.5 \%$ & $2.9 \%$ & $30.8 \%$ & $32.3 \%$ & $19.6 \%$ \\
\hline & Average & & 9,510 & $34.0 \%$ & $5.3 \%$ & $29.4 \%$ & $20.4 \%$ & $10.9 \%$ \\
\hline \multicolumn{9}{|c|}{ Note: Incom e figures were deflated to 2004 prices using rural consum er price index. } \\
\hline \multicolumn{9}{|c|}{ The exchange rate in 2004 was M K M alaw i Kwacha) 107 per U.S. do llar. } \\
\hline \multicolumn{9}{|c|}{$\begin{array}{l}\text { Adult Equ Nalent Un it (AEU) : } \mathrm{m} \text { ale } 15 \text { years or o der }=1 ; \text { fem ale } 15 \text { years or o der }=0.8 ; \mathrm{m} \text { ale or fem ale } 14 \\
\text { years or under }=0.5 \text {. }\end{array}$} \\
\hline
\end{tabular}




\begin{tabular}{|c|c|c|c|c|c|}
\hline $\begin{array}{l}\text { Access to } \\
\mathrm{m} \text { ajr tow } \mathrm{n}\end{array}$ & Study village & Poor & M iddle & Rich & $\begin{array}{l}\text { Pattem of } \\
\text { re lationsh ip }\end{array}$ \\
\hline \multirow{5}{*}{$\mathrm{B}$ ad } & $\begin{array}{c}\text { Kacham ba } \\
2004\end{array}$ & $100 \%$ & $65 \%$ & $4 \%$ & negative \\
\hline & $\begin{array}{c}\text { Kacham ba } \\
2009\end{array}$ & $51 \%$ & $20 \%$ & $6 \%$ & negative \\
\hline & B e b 2004 & $33 \%$ & $34 \%$ & $64 \%$ & positive \\
\hline & M u law a 2005 & $14 \%$ & $44 \%$ & $31 \%$ & $\begin{array}{l}\text { nverted U- } \\
\text { shaped }\end{array}$ \\
\hline & Ep ph i 2015 & $43 \%$ & $30 \%$ & $66 \%$ & U-shaped \\
\hline M oderate & Horo 2005 & $100 \%$ & $85 \%$ & $100 \%$ & U-shaped \\
\hline \multirow{6}{*}{ Good } & $\begin{array}{c}\text { B ongo b b } \\
2005\end{array}$ & $51 \%$ & $49 \%$ & $80 \%$ & $\begin{array}{c}\text { non- } \\
\text { existent }\end{array}$ \\
\hline & M bila 2005 & $100 \%$ & $100 \%$ & $82 \%$ & $\begin{array}{c}\text { non- } \\
\text { existent }\end{array}$ \\
\hline & Chalya 2009 & $42 \%$ & $64 \%$ & $84 \%$ & pos itive \\
\hline & Chalya 2014 & $100 \%$ & $80 \%$ & $87 \%$ & U-shaped \\
\hline & Yam ba 2009 & $54 \%$ & $76 \%$ & $67 \%$ & $\begin{array}{l}\text { nverted U- } \\
\text { shaped }\end{array}$ \\
\hline & Yam ba 2014 & $47 \%$ & $57 \%$ & $99 \%$ & pos itive \\
\hline \multicolumn{6}{|c|}{$\begin{array}{l}\text { Note: For ease of com parison, when negative own-farm ncom e is } \\
\text { com pensated by positive off-fam ncome, the share of off-fam ncome is } \\
\text { ndicated as } 100 \text { percent }\end{array}$} \\
\hline
\end{tabular}

\begin{tabular}{|c|c|c|c|c|c|c|c|c|c|c|}
\hline \multirow[b]{2}{*}{$\begin{array}{c}\text { Access to } \\
\text { major } \\
\text { town }\end{array}$} & \multirow[b]{2}{*}{ Study village (vear) } & \multirow[b]{2}{*}{$\begin{array}{l}\text { num ber } \\
\text { of } \\
\text { samples }\end{array}$} & \multirow{2}{*}{$\begin{array}{l}\mathrm{Gini} \\
\text { coeffic ient } \\
\text { of per AEU } \\
\text { total incom e }\end{array}$} & \multicolumn{5}{|c|}{ Change of $\mathrm{G}$ in coeffic ient } & \multirow{2}{*}{$\begin{array}{c}\text { Gini } \\
\text { coeffic ient } \\
\text { of per AEU } \\
\text { own-farm } \\
\text { ncome }\end{array}$} & \multirow{2}{*}{$\begin{array}{c}\text { Gini } \\
\text { coeffic ient } \\
\text { of per AEU } \\
\text { farm size }\end{array}$} \\
\hline & & & & $\begin{array}{l}\text { w ithout } \\
\text { caual labor } \\
\text { (ganyu) }\end{array}$ & $\begin{array}{l}\text { w ithout off- } \\
\text { farm se If } \\
\text { em p bym ent }\end{array}$ & $\begin{array}{l}\text { without } \\
\text { salaried jo }\end{array}$ & $\begin{array}{l}\text { without } \\
\text { other off- } \\
\text { farm incom e }\end{array}$ & $\begin{array}{l}\text { w ithout all } \\
\text { off-fam } \\
\text { ncome }\end{array}$ & & \\
\hline \multirow{5}{*}{$\mathrm{B}$ ad } & Kacham ba (2004) & 23 & 0.56 & 0.01 & 0.07 & 0.04 & 0.00 & 0.12 & 0.69 & 0.32 \\
\hline & Kacham ba (2009) & 23 & 0.55 & 0.02 & 0.03 & 0.00 & 0.00 & 0.06 & 0.61 & 0.35 \\
\hline & Beb (2004) & 30 & 0.49 & 0.01 & 0.04 & 0.02 & -0.01 & 0.06 & 0.56 & 0.54 \\
\hline & Mu law a (2005) & 28 & 0.43 & 0.02 & 0.01 & 0.00 & 0.04 & 0.10 & 0.53 & 0.36 \\
\hline & Epphi (2015) & 57 & 0.54 & 0.07 & 0.00 & -0.05 & 0.00 & -0.05 & 0.49 & 0.29 \\
\hline Moderate & Horo (2005) & 33 & 0.70 & 0.04 & 0.08 & 0.00 & 0.05 & 0.13 & 0.83 & 0.42 \\
\hline \multirow{6}{*}{ Good } & B ongo b b (2005) & 33 & 0.51 & 0.02 & -0.03 & 0.06 & 0.00 & 0.06 & 0.57 & 0.33 \\
\hline & M bila (2005) & 32 & 0.58 & 0.05 & 0.12 & 0.08 & -0.07 & 0.20 & 0.79 & 0.41 \\
\hline & Chalya (2009) & 18 & 0.44 & 0.03 & 0.00 & 0.03 & 0.02 & -0.09 & 0.35 & 0.33 \\
\hline & Chalya (2014) & 18 & 0.55 & 0.04 & 0.02 & -0.04 & 0.02 & 0.07 & 0.62 & 0.33 \\
\hline & Yam ba (2009) & 17 & 0.45 & 0.02 & 0.04 & 0.04 & 0.05 & 0.09 & 0.53 & 0.23 \\
\hline & Yam ba (2014) & 17 & 0.54 & 0.02 & 0.09 & 0.01 & -0.02 & -0.15 & 0.38 & 0.26 \\
\hline
\end{tabular}

